\title{
Stepwise incorporation of white clover (Trifolium repens L.) as fertiliser increases nitrogen fixation and improves nitrogen retention when intercropped with leek (Allium porrum L.)
}

\author{
Yue Xie • Jorn Nygaard Sorensen - Karen Koefoed Petersen • \\ Hanne Lakkenborg Kristensen
}

Received: 29 May 2017 / Accepted: 16 October 2017 /Published online: 18 November 2017

(C) The Author(s) 2017. This article is an open access publication

\begin{abstract}
Background and aims We investigated whether the incorporation of intercropped white clover as a split-dose fertiliser improves $\mathrm{N}$ retention of the plant-soil system in leek production.

Methods White clover and leek were grown in pots where clover was stepwise incorporated into soil as fertiliser. Half of the clover was incorporated before leek transplantation (LT), the other half was incorporated 26 (S1) or 41 (S2) days after LT, compared with full incorporation of all clover (F) before LT. ${ }^{15} \mathrm{~N}$ injection and leaching studies were performed to investigate interspecific competition and the effects of precipitation on soil $\mathrm{N}$ availability.

Results Stepwise incorporations increased or had no effect on leek growth, despite competition for $\mathrm{N}$ between white clover and leek. Compared to F, leek grown with stepwise incorporations had similar and lower $\mathrm{N}$ accumulation before the second incorporation, but $\mathrm{N}$ was higher at the end of the experiment. $\mathrm{N}_{2}$ fixation by white clover increased the total $\mathrm{N}$ input into soil and matched $\mathrm{N}$ availability with leek $\mathrm{N}$ demand and growth
\end{abstract}

Responsible Editor: Richard J. Simpson

Electronic supplementary material The online version of this article (https://doi.org/10.1007/s11104-017-3471-y) contains supplementary material, which is available to authorized users.

Y. Xie · J. N. Sorensen - K. K. Petersen •

H. L. Kristensen $(\bowtie)$

Department of Food Science, Aarhus University, Kirstinebjergvej 10, 5792 Aarslev, Denmark

e-mail: hanne.kristensen@food.au.dk rate. Loss of inorganic $\mathrm{N}$ by leaching was lowest in $\mathrm{S} 2$ and highest in F.

Conclusions Stepwise incorporations of white clover improved $\mathrm{N}$ retention in the plant-soil system and could be used to increase leek yield.

Keywords Catch crop · Competition · Green manure · Net mineralisation $\cdot$ Nitrate leaching

\section{Introduction}

Maintenance of soil $\mathrm{N}$ fertility in organic agroecosystems relies heavily on the input of organic materials, such as fresh, composted or digested plant biomass or animal manure, and $\mathrm{N}_{2}$ fixation by legumes. In addition the management of crop residues and an optimized crop rotation are important. However, fertilisation of vegetable crops by animal manure might carry risks of contaminating edible parts of vegetables by intestinal parasites and pathogens if proper management practises are not respected (Hussain et al. 2014). Also the reduced availability of organic certified animal manure could increase the use of off-farm fertilisers of animal origin allowed in organic farming. An alternative approach is to use green manure as $\mathrm{N}$ source. Legume-based green manures may provide 32-149 $\mathrm{kg} \mathrm{N} \mathrm{ha}^{-1}$ through $\mathrm{N}_{2}$ fixation for the growing crops (Mueller and Thorup-Kristensen 2001) and increase the total amount of $\mathrm{N}$ in the $\mathrm{N}$ cycle of agroecosystems. For example, red clover (Trifolium pratense L.) can accumulate $133 \mathrm{~kg} \mathrm{~N} \mathrm{ha}^{-1}$ from the time of sowing to the following spring as reported by Båth 
(2001). Once incorporated into the soil, the $\mathrm{N}$ mineralisation rate of the green manure is influenced by the physical and biochemical properties (Chaves et al. 2004). Soil properties, such as texture (Bosatta and Agren 1997), organic matter, water contents and temperature (Cassman and Munns 1980; Cookson et al. 2005), also play important roles. By introducing green manure and applying crop residues back to the soil, the $\mathrm{N}$ input and output of cropping systems can be balanced and controlled in a way to supply adequate $\mathrm{N}$ for growing crops. The amount of $\mathrm{N}$ provided to crops by green manure depends on when the green manure is sown (Sorensen 1992; Vos and van der Putten 1997), when the manure is incorporated in the soil (Odhiambo and Bomke 2001) and plant species of green manure. In practice, the actual crop yield is often lower than the potential yield due to poor synchronisation between the net mineralisation of green manure and $\mathrm{N}$ demand by crops at different growth stages. This asynchronicity may lead to low $\mathrm{N}$ recovery and potentially high losses of nitrate by leaching, both during the growing season and after harvest (Campiglia et al. 2011).

One method for reducing $\mathrm{N}$ loss in soil is to intercrop cash crops with cover crops. This technique can reduce water percolation and soil $\mathrm{N}$ concentrations by increasing the soil volume exploited by roots, especially for shallow-rooted crops, such as leeks (Allium porrum L.) (Liedgens et al. 2004; Xie et al. 2016). An intercropping system can be formed by rotovating an overwintering cover crop in strips alternating with strips of the cover crops kept growing in autumn, and then growing cash crops in the strips of bare soil in spring. The strips of the cover crop are then incorporated after the growing season or during winter (Båth et al. 2008). This method will potentially reduce nitrate leaching early in the growing season, when the cash crop has a small root system and low demand for N (Xie and Kristensen 2017). However, interspecific competition for nutrients, water and light may hamper crop yield. For example, competition for $\mathrm{N}$ might be intense when the soil is the only source of $\mathrm{N}$. Additionally, when two plant species coexist, $\mathrm{N}$ uptake of one species can be inhibited in response to a reduction in root distribution caused by competition for soil space (Andersen et al. 2014). Intercropped legumes are assumed to be less competitive for soil $\mathrm{N}$ due to their ability to fix $\mathrm{N}_{2}$ (Jensen 1996). Although strong competition between legumes and vegetables has been found, competition can be controlled by 1) pruning the roots to reduce belowground competition (Båth et al.
2008), 2) postponing the sowing of cover crops until later in the growing season or 3) using a substitutive field design that keeps the total plant density the same in the intercropping system as in the sole-crop system (Xie and Kristensen 2017).

Another way to reduce soil $\mathrm{N}$ loss is to improve $\mathrm{N}$ recovery by optimising application of fertiliser. Splitdose fertilisation is a well-known method used in conventional cropping systems to meet a crop's increasing demand for $\mathrm{N}$ during the growing season and reduce early season leaching of soil nitrate. In this method, the fertiliser amendment is split into two or more doses, with one dose added at the initial planting of the crop and the other(s) in mid-season (Thompson et al. 2017).

In this study, we tested whether stepwise incorporation of intercropped white clover (Trifolium repens L) used as a split-dose fertiliser, can improve the $\mathrm{N}$ uptake of organically grown leeks. Stepwise incorporation of white clover into soil was compared to the incorporation of all clover at initial leek transplantation in terms of $\mathrm{N}$ retention. In a greenhouse experiment, we assessed two dates for the second incorporation of white clover in the stepwise incorporations into two soil types.

It was hypothesised that stepwise incorporation of white clover before leek transplanting and during the growing season would (1) better synchronise plantavailable $\mathrm{N}$ and $\mathrm{N}$ demand in leeks, (2) increase $\mathrm{N}$ input from clover $\mathrm{N}_{2}$ fixation, leading to higher leek biomass and $\mathrm{N}$ content, and (3) reduce nitrate leaching during the growing season compared to full incorporation of clover before leek transplanting. We further hypothesised that (4) the competition for $\mathrm{N}$ between stepwise incorporated white clover and leek would be negligible.

\section{Materials and methods}

\section{Experimental design}

A pot experiment was conducted in 2015 at Aarhus University, Aarslev. Two factors were investigated by using a completely randomised design: incorporation strategies of green manure ( $n=3$ treatments) and soils $(n=2)$. Variations were replicated four times, yielding 24 experimental units. Six pots were included in each experimental unit. Experimental units were arranged randomly on six tables in the greenhouse, and each table contained four units. To observe the status of the simulated agroecosystem at different 
intervals during the growing season, plant material and soil were sampled destructively six times.

White clover was either full-incorporated into the soil just before leeks were transplanted (treatment F) or was stepwise incorporated at two dates (treatments S1 and $\mathrm{S} 2$ ). In the S1 and S2, half of the white clover was harvested and incorporated into the soil in situ before leeks were transplanted. The remaining half of the white clover was incorporated into the soil in situ as it was harvested at 26 days (treatment S1, early stepwise incorporation) or 41 days (treatment S2, late stepwise incorporation) after leeks were transplanted (Fig. 1, Table 1). Until the second incorporation of white clover, there was no difference between treatments $\mathrm{S} 1$ and S2; therefore, these samples were combined into one treatment (S1/S2) at the first three sampling dates (D1-D3).

Prior to incorporation, white clover was sown at a density of 236 seeds $\mathrm{m}^{-2}$ on February 16, 2015 and irrigated every second day in pots $(35 \mathrm{~cm}$ diameter; $22 \mathrm{~cm}$ in height) to mimic overwintering green manure. Each pot was divided into two parts for the stepwise incorporation. To obtain a homogeneous distribution of white clover in all pots, on March 24 plantlets were either transplanted or removed to guarantee that 10 white clover plants occurred in each pot half. On May 2-8 (11 weeks after sowing the white clover), clover was cut and incorporated (as fertiliser) into the soil of the treatment pots in either both pot halves (treatment F) or only one half of a pot (treatments S1 and S2) (Fig. 1, Table 1). In the stepwise incorporation treatments, the other half of white clover was not incorporated until June 16-19 (D3/S1) or July 1-2 (D4/S2).

Incorporation of white clover followed a two-step process: (1) aboveground biomass of white clover was cut into approximately 8 -cm-long pieces and mixed with soil from the top $10 \mathrm{~cm}$ soil layer, from either the entire pot (treatment F) or half of the pot (treatments S1 and S2); (2) after mixing well, the clover and soil mixture was put back into the pots (both full and half pots) and pressed to a bulk density close to $1.33 \mathrm{~g}$ $\mathrm{cm}^{-3}$. On May 22 (D2, Fig. 1), two leek seedlings of similar size were transplanted into each pot where the white clover had been added. White clover roots were pruned to mimic root pruning in the field (Båth et al. 2008). To prune, a 35 -cm-wide metal spade was positioned between the two half parts of the pot and pressed vertically down into the soil to the bottom of the pot, taking care not to cut the white clover aboveground. Pruning occurred in treatments S1 and S2 at the time of leek transplantation and again in treatment $\mathrm{S} 2$ at the time of the second incorporation of clover in treatment S1 (D3). After leeks were transplanted, the aboveground portion of white clover was restricted to its own half of the pot by a plastic string, to avoid light competition between the white clover and leek. A saucer was put underneath each pot to prevent loss of soil solution. Details on sampling dates, pots, plants and soil samples are shown in Table 1.

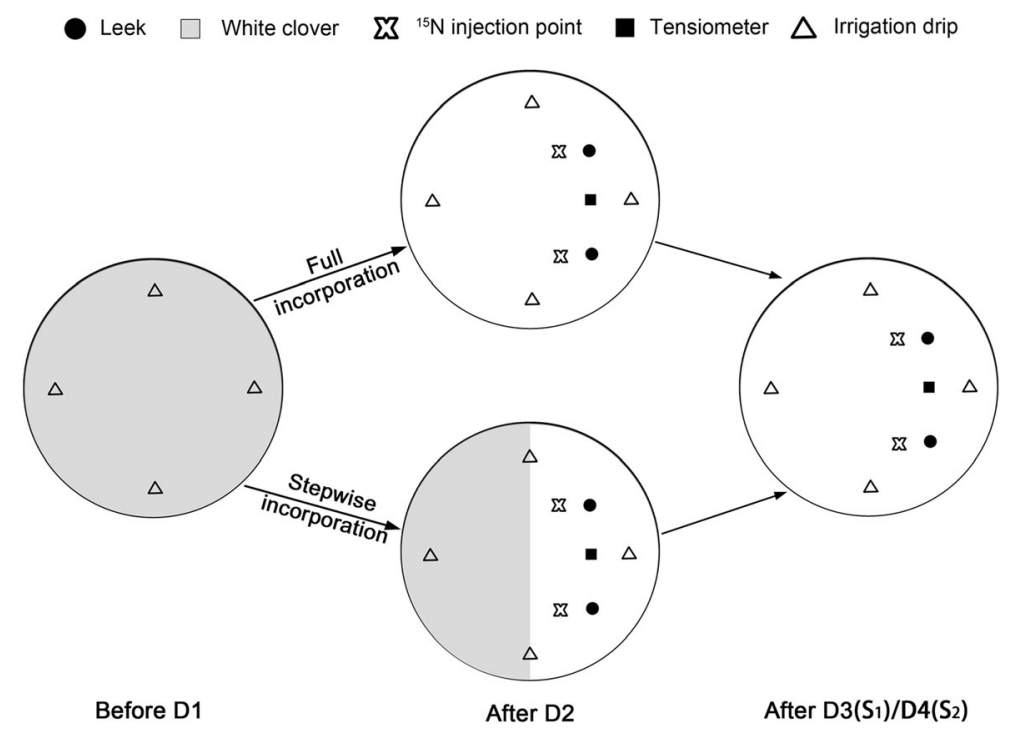

Fig. 1 Schematic diagram showing the position of leeks, tensionmeters (only in pots sampled August 19/D6), drips and the ${ }^{15} \mathrm{~N}$ injection points in pots. The positions were unchanged after incorporation of white clover. The abbreviations of D1, D2, D3, D4, S1and S2 are explained in Table 1 
Table 1 Experimental conditions, by date. Abbreviations: WC (white clover), F (full incorporation), S1 (early stepwise incorporation), and S2 (late stepwise incorporation). Sampling times (D1-

\begin{tabular}{|c|c|c|c|c|c|}
\hline $\begin{array}{l}\text { Sampling } \\
\text { time }\end{array}$ & $\begin{array}{l}\text { Sampling } \\
\text { date }\end{array}$ & $\begin{array}{l}\text { Experimental } \\
\text { stage }\end{array}$ & $\begin{array}{l}\text { Plant samples } \\
\text { (species: number } \\
\text { (treatments)) }\end{array}$ & $\begin{array}{l}\text { Soil samples } \\
\text { (number } \\
\text { (treatments)) }\end{array}$ & $\begin{array}{l}\text { No. of pots } \\
\text { used }\end{array}$ \\
\hline D1 & May 8 & $\begin{array}{l}\text { Full incorporation/first half of stepwise } \\
\text { incorporations S1 and S2 }\end{array}$ & WC: 8 & 8 & 8 \\
\hline \multirow[t]{2}{*}{ D2 } & May 22 & Leek transplanting & WC: 8 (S1/S2) & $16(\mathrm{~F}, \mathrm{~S} 1 / \mathrm{S} 2)$ & 16 \\
\hline & June 11 & ${ }^{15} \mathrm{~N}$ injection & - & - & - \\
\hline \multirow[t]{2}{*}{ D3 } & June 17 & Second half of stepwise incorporation S1 & $\begin{array}{l}\text { WC: } 8(\mathrm{~S} 1 / \mathrm{S} 2) \\
\text { Leek: } 16(\mathrm{~F}, \mathrm{~S} 1 / \mathrm{S} 2)\end{array}$ & $16(\mathrm{~F}, \mathrm{~S} 1 / \mathrm{S} 2)$ & 16 \\
\hline & June 25 & ${ }^{15} \mathrm{~N}$ injection & - & - & - \\
\hline D4 & July 1 & Second half of stepwise incorporation S2 & $\begin{array}{l}\text { WC: } 8 \text { (S2) } \\
\text { Leek: } 24 \text { (F, S1, S2) }\end{array}$ & $24(\mathrm{~F}, \mathrm{~S} 1, \mathrm{~S} 2)$ & 24 \\
\hline D5 & July 22 & Five/three weeks after second incorporations & Leek: 24 (F, S1, S2) & $24(\mathrm{~F}, \mathrm{~S} 1, \mathrm{~S} 2)$ & 24 \\
\hline D6 & August 19 & Nine/seven weeks after second incorporations & Leek: 24 (F, S1, S2) & $24(\mathrm{~F}, \mathrm{~S} 1, \mathrm{~S} 2)$ & 24 \\
\hline
\end{tabular}

6), represent the dates on which treatments are sampled. A dash means the entry is not applicable
Growing conditions

In this experiment, two soils were used: a sandy loam (Typic Agrudalf located at Aarslev $10^{\circ} 27^{\prime} \mathrm{E}, 55^{\circ} 18^{\prime} \mathrm{N}$ ) and a loamy sand (Typic Hapludult located at Foulum $56^{\circ} 30^{\prime} \mathrm{N}, 09^{\circ} 35^{\prime} \mathrm{E}$ ) (Xie and Kristensen 2017; Olesen et al. 2000). Soil was obtained in January 2015 from the top soil layer $(0-0.2 \mathrm{~m})$ of fields that had been managed according to organic regulations since 1996 (Aarslev) and 2007 (Foulum). In 2014, the Aarslev soil was fallow after a crop of barley (Hordeum vulgare L.) with undersown grass clover in 2013. The fertilisation strategy was based on $\mathrm{N}$ fixation by legumes. The Foulum soil had been cropped with oats (Avena sativa L.) after a crop of barley in 2013. The fertilisation strategy was based on application of animal manure and biogas slurry made from animal manure. Soil was sieved through a 5$\mathrm{mm}$ mesh, mixed with sand to $33 \%$ (by volume) to improve soil structure. Then, it was packed into pots layer by layer as uniformly as possible until soil in each pot attained a bulk density of $1.33 \mathrm{~g} \mathrm{~cm}^{-3}$ and a dry

weight of $24.5 \mathrm{~kg}$. Final characteristics of the soils are shown in Table 2.

The greenhouse temperature set point was $20^{\circ} \mathrm{C}$ during the day and $16{ }^{\circ} \mathrm{C}$ at night. Supplementary light provided a photoperiod of $16 \mathrm{~h} \mathrm{~d}^{-1}$ until May 4 . After this date, the greenhouse windows were opened when the temperature exceeded $10{ }^{\circ} \mathrm{C}$, and the greenhouse was heated when the temperature fell below $5{ }^{\circ} \mathrm{C}$.

Pots were irrigated with rainwater and irrigation was controlled by tensiometers, which were installed on April 10, 2015 at a depth of $20 \mathrm{~cm}$ in pots for the last sampling date in each experimental unit. Each treatment had four tensiometers, corresponding to an irrigation group. Irrigation started when two tensiometers in one irrigation group reached a tension below $-100 \mathrm{kPa}$. Each pot contained four drippers and received $280 \mathrm{~mL}$ of rainwater in total during each irrigation. Total volumes of water used for irrigation in Aarslev soil were $32 \mathrm{~L}$ (treatment F), $37 \mathrm{~L}$ (treatment S1) and $40 \mathrm{~L}$ (treatment S2) and in Foulum soil were $37 \mathrm{~L}$ (treatment F), $42 \mathrm{~L}$ (treatment S1) and $45 \mathrm{~L}$ (treatment S2).

Table 2 The main characteristics of the soils from the sites of Aarslev and Foulum at the start of the experiment after addition of 33\% sand

\begin{tabular}{llllllllllll}
\hline Soil & $\begin{array}{l}\text { Coarse sand } \\
\left(\mathrm{g} \mathrm{kg}^{-1}\right)\end{array}$ & Fine sand & Silt & Clay & Humus & Total C $\begin{array}{l}\text { Total N Inorganic N } \\
\left(\mathrm{mg} \mathrm{kg}^{-1}\right)\end{array}$ & $\mathrm{P}\left(\mathrm{NaHCO}_{3}\right)$ & $\left.\mathrm{K}\left(\mathrm{CH}_{3} \mathrm{COONH}\right)_{4}\right)$ & $\mathrm{pH}(\mathrm{water})$ \\
\hline Aarslev & 590 & 280 & 51 & 63 & 1.6 & 14 & 700 & 4.5 & 33 & 92 & 7.5 \\
Foulum & 540 & 310 & 68 & 62 & 2.4 & 23 & 1300 & 7.7 & 69 & 58 & 7.2 \\
\hline
\end{tabular}


${ }^{15} \mathrm{~N}$ injections

To study the competition for $\mathrm{N}$ between leeks and white clover, ${ }^{15} \mathrm{~N}$ was injected at two points in each pot on June 11 and 25 (i.e. 5 days before sampling on D3 and D4). Positions of leeks, tensiometers (only in pots sampled on D6), drips and injection points in the pots are shown in Fig. 1. Each pot had a surface area of $0.096 \mathrm{~m}^{2}$ and received $13.2 \mathrm{mg}$ ${ }^{15} \mathrm{~N}$ according to the injection method described by Čereković et al. (2013) and ${ }^{15} \mathrm{~N}$ labelling of the soil $\mathrm{N}_{\text {inorg }}$ described by Kristensen and ThorupKristensen (2004). For this experiment, $3 \mathrm{~mL}$ of $\mathrm{Na}^{15} \mathrm{NO}_{3}$ solution $(99 \%$ enriched) was injected at each injection point $\left(13.6 \mathrm{mg} \mathrm{mL}^{-1}\right)$. To distribute the solution in the 0 to $7 \mathrm{~cm}$ soil layer, a $5 \mathrm{~mL}$ capacity syringe with a $7 \mathrm{~cm}$ long needle was inserted into the soil vertically and pulled out slowly during the injection process. To allow the soil to absorb the solution, the irrigation system was turned off $12 \mathrm{~h}$ before injection and turned on $24 \mathrm{~h}$ after the injection.

\section{Leaching events}

Leaching experiments were conducted 1 day before the second incorporation in treatments S1 and S2 (D3 and D4), corresponding to 4 days after ${ }^{15} \mathrm{~N}$ injection, allowing time for plant ${ }^{15} \mathrm{~N}$ uptake. Pots were placed in boxes for collection of resulting leachate. A volume of $3.64 \mathrm{~L}$ of rainwater (equivalent to $38 \mathrm{~mm}$ of precipitation, mimicking a large rain event) was given to each pot gradually over $3 \mathrm{~h}$. After adding rainwater, all pots were kept in boxes for $1 \mathrm{~h}$ before sampling to allow drainage of excess water through holes at the bottoms of the pots. Leachate from each sampled pot was mixed well and subsampled for nutrient analysis. Remaining leachate and leachates from non-sampled pots were discarded to mimic nitrate leaching losses by heavy precipitation.

Plant, soil and leachate analysis

Aboveground biomass (fresh weight) of white clover was determined on May 8 (D1), May 22 (D2/ LT), June 17 (D3/second incorporation in S1) and July 1 (D4/second incorporation in S2). Aboveground biomass of leeks was determined on June 17 (D3), July 1 (D4), July 22 (D5, 5 and 3 weeks after second incorporation in S1 and S2) and August 19
(D6, 9 and 7 weeks after second incorporation in S1 and S2) (Table 1). Roots of white clover were sampled at the first four sampling dates. Two subsamples were made by dividing pots into two parts perpendicularly to the middle line. Root biomass and soil were sampled separately from each subsample. Most roots were picked out manually by using a standardised procedure and rinsed with tap water to remove all soil. Dry matter contents of white clover (aboveground and root biomass) and leek were determined after oven-drying at $80{ }^{\circ} \mathrm{C}$ for $20 \mathrm{~h}$ (Jones and Case 1990).

Aboveground biomasses of white clover and leek, sampled at the time of the second incorporation (D3 and D4 for treatments S1 and S2), were prepared for ${ }^{15} \mathrm{~N}$ and total $\mathrm{N}$ analysis. First, samples were milled and mixed very well. Then, two subsamples were ground finely $(<0.05 \mathrm{~mm})$, encapsulated by a tin container and sent to the Stable Isotope Facility of the University of California at Davis, according to their instructions. Additional plant samples were taken from pots that had not received ${ }^{15} \mathrm{~N}$ injection to determine the natural abundance of ${ }^{15} \mathrm{~N}$. All samples were analysed with a PDZ Europa ANCA-GSL elemental analyser interfaced with a PDZ Europa 20-20 isotope ratio mass spectrometer (Sercon Ltd., Cheshire, UK). Other plant samples were analysed for total $\mathrm{N}$ with the VDLUFA method (VDLUFA 1991), by burning plant material at $900{ }^{\circ} \mathrm{C}$ and determining the molecular $\mathrm{N}$ by LECO TruSpec CN (St. Joseph, Michigan). Soil subsamples were taken after roots had been removed and the soil had been mixed well.

Volume was determined for the leachate collected from individual pots before the second incorporations in treatments $\mathrm{S} 1$ and $\mathrm{S} 2$. A subsample of $200 \mathrm{~mL}$ of leachate was collected for inorganic $\mathrm{N}\left(\mathrm{N}_{\text {inorg }}\right)$ analysis. Soil and leachate samples were immediately frozen and kept at $-18{ }^{\circ} \mathrm{C}$ until analysis for $\mathrm{N}_{\text {inorg }}$ by standard colorimetric methods using AutoAnalyzer 3 (Bran + Luebbe, Germany). Before $\mathrm{N}_{\text {inorg }}$ analysis, a $100 \mathrm{~g}$ subsample of soil (fresh weight) was extracted with $1 \mathrm{M} \mathrm{KCl}$ for $1 \mathrm{~h}$ (1 part soil: 2 parts solution) and centrifuged. The supernatant was analysed for $\mathrm{NH}_{4}{ }^{+}$and $\mathrm{NO}_{3}{ }^{-}$content.

\section{Data analysis}

To evaluate interspecific competition for $\mathrm{N}$ and the ability of plants to take up $\mathrm{N},{ }^{15} \mathrm{~N}$ uptake and ${ }^{15} \mathrm{~N}$ 
recovery (\%) were calculated according to eqs. (1) and (2) below (Malhi et al. 2004):

${ }^{15} \mathrm{~N}$ uptake $=$ Plant dry weight $\times \mathrm{N}$ concentration $\times(b-a)$

$\mathrm{N}$ recovery $(\%)=\frac{\mathrm{N}_{\text {acc }} \times(b-a)}{{ }^{15} \mathrm{~N}_{\text {injected }}} \times 100$

where $b$ and $a$ are the percentages of ${ }^{15} \mathrm{~N}$ atoms in plant materials from pots injected or not injected (natural abundance) with ${ }^{15} \mathrm{~N}$, respectively; $\mathrm{N}_{\text {acc }}$ is the plant $\mathrm{N}$ accumulation; and ${ }^{15} \mathrm{~N}_{\text {injected }}$ is the amount of ${ }^{15} \mathrm{~N}$ injected into each pot. $\mathrm{N}$ use efficiency (NUE) was calculated by eq. (3) (Zotarelli et al. 2008):

$\operatorname{NUE}(\%)=\mathrm{N}_{\text {leek }} /\left(\mathrm{N}_{\text {input }}+\mathrm{N}_{\text {soil }}\right) \times 100$

where $\mathrm{N}_{\text {leek }}$ is the amount of $\mathrm{N}$ accumulated in leeks by D6; and $\mathrm{N}_{\text {input }}$ is the amount of $\mathrm{N}$ that was accumulated in white clover at D1 $\left(\mathrm{N}_{\text {clover }}\right)$ and was fixed by white clover after D1 $\left(\mathrm{N}_{\text {fixed }}\right)$, which was only relevant for treatments $\mathrm{S} 1$ and S2 (Table 3). $\mathrm{N}_{\text {soil }}$ is the soil inorganic $\mathrm{N}$ at D1.

$\mathrm{N}_{\text {fixed }}$ after D1 (in stepwise incorporations) was calculated as the difference between the amount of $\mathrm{N}$

Table 3 The effects of incorporation strategy and soil on the amount of white clover $\mathrm{N}$ input, $\mathrm{N}$ fixed, $\mathrm{N}$ taken up by plants after D1, and N use efficiency (NUE) of leek, based on N input from white clover and soil inorganic $\mathrm{N}$ at D1

\begin{tabular}{|c|c|c|c|c|}
\hline \multirow[b]{2}{*}{ Factor } & \multicolumn{3}{|c|}{ White clover } & \multirow{2}{*}{$\begin{array}{l}\text { Leek } \\
{ }^{\dagger} \mathrm{NUE} \text { at } \\
\text { D6 (\%) }\end{array}$} \\
\hline & $\begin{array}{l}* \mathrm{~N} \text { input } \\
\left(\mathrm{g} \mathrm{pot}^{-1}\right)\end{array}$ & $\begin{array}{l}{ }^{\dagger} \mathrm{N} \text { fixed } \\
\text { after } \\
\mathrm{D} 1\left(\mathrm{~g} \mathrm{pot}^{-1}\right)\end{array}$ & $\begin{array}{l}{ }^{\dagger} \mathrm{N} \text { uptake } \\
\text { from soil after } \\
\text { D1 }\left(\mathrm{g} \mathrm{pot}^{-1}\right)\end{array}$ & \\
\hline
\end{tabular}

Soil

$\begin{array}{ccccc}\text { Aarslev } & 3.1 & 1.7 & 0.2 & 20.4 \\ \text { Foulum } & 3.4 & 1.4 & 0.5 & 21.3 \\ \text { Incorporation } & & & \\ \text { F / D1 } & 2.2 \mathrm{~b} & - & - & 19.4 \\ \mathrm{~S} 1 / \mathrm{D} 3 & 3.7 \mathrm{a} & 1.5 & 0.2 & 21.6 \\ \mathrm{~S} 2 / \mathrm{D} 4 & 3.8 \mathrm{a} & 1.6 & 0.5 & 21.5\end{array}$

The abbreviations of F, S1, S2, D1, D3 and D4 are explained in Table 1. The different letters indicate significant differences at $p<0.05$. A dash means the entry is not applicable

*N input is the total amount of $\mathrm{N}$ accumulated at D1 and $\mathrm{N}$ fixed after D1, which was relevant for S1 and S2

$\dagger \mathrm{N}$ fixed and $\mathrm{N}$ uptake from soil of white clover (after D1) and NUE of leek were estimated based on an $\mathrm{N}$ balance calculation and assumptions in Online Resource 1 accumulated in white clover after D1 and the amount of $\mathrm{N}$ taken up by white clover from the soil during the period, taking into account (via a balance calculation) the $\mathrm{N}$ mineralised in treatment $\mathrm{F}, \mathrm{N}$ uptake by leeks, $\mathrm{N}$ in leachates and soil $\mathrm{N}_{\text {inorg. }}$. This calculation was based on the assumption that denitrification, $\mathrm{N}$ volatilisation, rhizodeposition of white clover and net $\mathrm{N}$ mineralisation/ immobilisation from soil organic matter were negligible. It was also assumed that the difference in mineralisation of white clover between treatments was only influenced by the amount of $\mathrm{N}$ from incorporated white clover. Details of the balance calculation are shown in Online Resource 1. The net mineralisation rate of white clover after the second clover incorporation was evaluated by determining the change in soil inorganic nitrogen $\left(\mathrm{N}_{\text {inorg }}\right)$ between the second incorporation and the next sampling date (D3 to D4 for S1, i.e. 15 days; $\mathrm{D} 4$ to $\mathrm{D} 5$ for S2, i.e. 21 days).

Effects of the stepwise incorporations and soils on leek growth and $\mathrm{N}$ dynamics were tested by using the general linear model procedure (software $\mathrm{R}$ version 3.02) for analysis of variance (F-test), with the Incorporation (F, S1 and S2), Soil (Aarslev and Foulum) and Incorporation $\times$ Soil as factors. The effect of Soil on the change in soil $\mathrm{N}_{\text {inorg }}$ from the second incorporation to the next sampling date was tested with Soil as a factor. The ${ }^{15} \mathrm{~N}$ uptake of leek and white clover in stepwise incorporations were compared for each soil separately with Sampling date (D3 and D4) and Plant species as factors. Multiple comparisons were based on Tukey's Student test when there were no interactions between Incorporation and Soil. When an interaction existed, multiple comparisons between treatments were conducted, by using LSMEANS. To obtain homogeneity of variance, data were transformed by the formula $y=x^{1 / 2}$ or $y=\log (x)$.

\section{Results}

Biomass and $\mathrm{N}$ in plants

Leeks sampled from D3 to D6 (Table 1) showed no significant differences in dry biomass and growth rate between the two adjacent sampling dates (results not shown) until D6, when an interaction was found between incorporation strategy and soil (Fig. 2a and b). In Aarslev soil, the dry biomass of leeks was higher in treatment S1 than treatment F ( $p<0.01$; Fig. 2a). Leek 


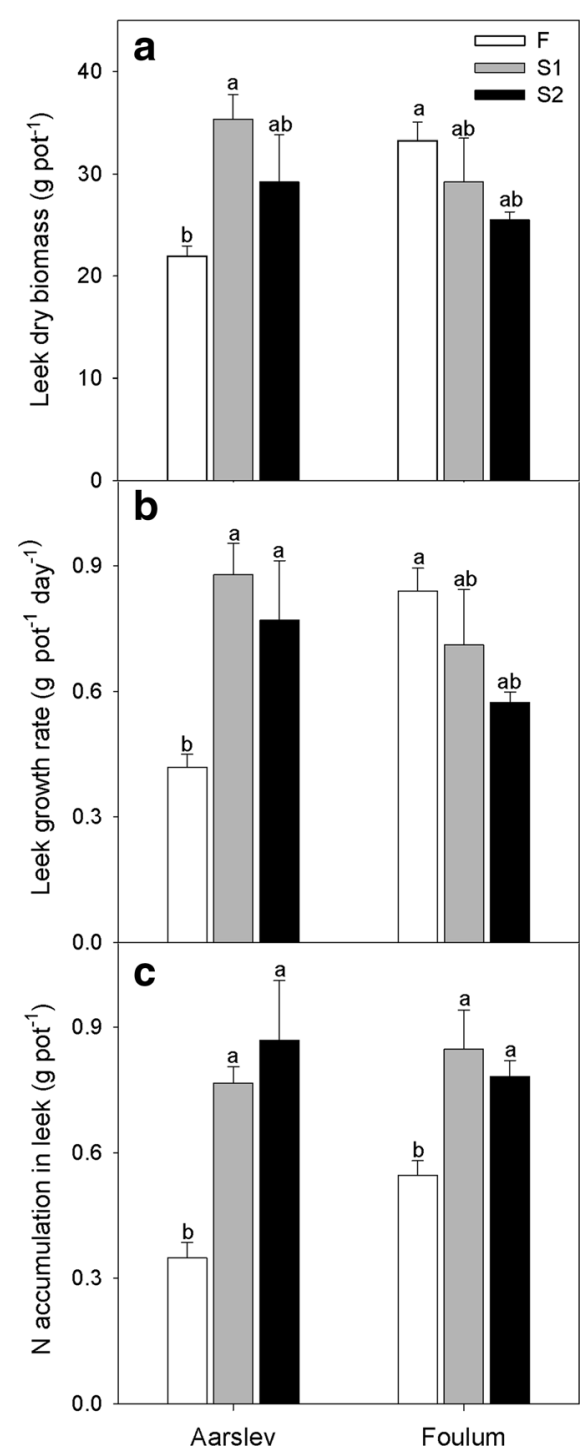

Fig. 2 The effect of incorporation strategies and soil on leek (a) dry biomass, (b) growth rate and (c) $\mathrm{N}$ accumulation at the end of the experiment (D6). The abbreviations F, S1 and S2 are explained in Table 1. The different letters indicate significant differences between all treatments at $p<0.05$. Error bars indicate standard errors of the mean

growth rates were higher in treatments $\mathrm{S} 1$ and $\mathrm{S} 2$ than in treatment $\mathrm{F}$ ( $p<0.05$, Fig. 2b). In Foulum soil, the dry biomass and growth rate of leeks were similar for the three incorporation strategies. The fresh biomass of leeks was in the range of 99-185 $\mathrm{g} \mathrm{plant}^{-1}$ at the end of the experiment (results not shown).

Leek $\mathrm{N}$ accumulation was similar in treatment $\mathrm{F}$ and in the stepwise incorporations at D3 and D5, being lower in S2 at D4 (Table 4). At D6, $\mathrm{N}$ accumulation was lower in treatment $\mathrm{F}$ than in treatments $\mathrm{S} 1$ and S2 (Fig. 2c). N input from white clover, consisting of $\mathrm{N}$ accumulated at $\mathrm{D} 1$ and $\mathrm{N}$ fixed after D1, was higher in treatments $\mathrm{S} 1$ and $\mathrm{S} 2$ than in $\mathrm{F}(p<0.01$, Table 3$)$. There was no significant difference in $\mathrm{N}$ taken up from soil by white clover or $\mathrm{N}$ fixed after D1 between treatments S1 and S2. The NUE of leek at the end of the experiment was similar among the three incorporation strategies (Table 3).

Soil $\mathrm{N}_{\text {inorg }}$ dynamics

Soil $\mathrm{N}_{\text {inorg }}$ in treatment $\mathrm{F}$ was higher than in treatment $\mathrm{S} 1 / \mathrm{S} 2$ at D2 and D3, and in treatments S1 and S2 at D4 across both soils (Fig. 3). When analysed separately for each soil, the soil $\mathrm{N}_{\text {inorg }}$ was similar in treatments $\mathrm{F}$ and S1 at D4 in Foulum soil. At D5 and D6, the difference between incorporation methods was not significant, but the soil $\mathrm{N}_{\text {inorg }}$ was higher in Foulum than in Aarslev soil $(p<0.01)$. We compared the changes in soil $\mathrm{N}_{\text {inorg }}$ concentration between the two soils after the stepwise incorporations (treatments S1 and S2; Table 5). From D3 to D4, an increase in soil $\mathrm{N}_{\text {inorg }}$ was observed in treatments $\mathrm{F}$ and $\mathrm{S} 1$, with the increase in $\mathrm{S} 1$ being higher in Foulum than in Aarslev soil. In treatment S2, soil $\mathrm{N}_{\text {inorg }}$ decreased, with a greater decrease in Aarslev than in Foulum soil. From D4 to D5, the change of soil $\mathrm{N}_{\text {inorg }}$ in $\mathrm{S} 1$ levelled out between the two soils; however, soil $\mathrm{N}_{\text {inorg }}$ in $\mathrm{S} 2$ increased more in Foulum than in Aarslev soil (Table 5).

Plant ${ }^{15} \mathrm{~N}$ uptake and leachates

At both times of ${ }^{15} \mathrm{~N}$ injection, leeks in treatments $\mathrm{F}, \mathrm{S} 1$ and S2 had similar ${ }^{15} \mathrm{~N}$ uptake values (Table 4). A similar result was found for the ${ }^{15} \mathrm{~N}$ recovery in leeks, which increased between the first and second injections from 2 to $2.4 \%$ to $19.5-23.1 \%$ in the three incorporation strategies. Compared to white clover, the stepwise incorporation resulted in lower ${ }^{15} \mathrm{~N}$ uptake by leeks in both soils at D3 (Fig. 4). The ${ }^{15} \mathrm{~N}$ uptake of white clover was lower at D4 than at D3, while uptake by leeks was higher. Total ${ }^{15} \mathrm{~N}$ recovery (including leeks and white clover) was higher in the stepwise incorporations than in treatment $\mathrm{F}$ at D3 (Table 4). At D4, total ${ }^{15} \mathrm{~N}$ recovery was higher in treatment $\mathrm{S} 2$ compared to $\mathrm{F}$ and $\mathrm{S} 1$, where only leeks were growing in the pots (no clover).

At D3, the leachate volume and the total $\mathrm{N}$ loss by leaching were lower in the stepwise (half-pot) incorporations than in the full-pot incorporation (Table 6). The $\mathrm{N}$ loss in treatment $\mathrm{F}$ accounted for $15.9 \%$ of the total 
Table 4 The effects of incorporation strategy and soil on leek biomass, $\mathrm{N}$ accumulation and ${ }^{15} \mathrm{~N}$ uptake and recovery

\begin{tabular}{|c|c|c|c|c|c|c|c|}
\hline \multirow{2}{*}{$\begin{array}{l}\text { Sampling } \\
\text { time }\end{array}$} & \multirow[t]{2}{*}{ Factor } & \multirow{2}{*}{$\begin{array}{l}\text { Dry biomass } \\
\left(\mathrm{g} \mathrm{pot}^{-1}\right)\end{array}$} & \multirow{2}{*}{$\begin{array}{l}\mathrm{N} \text { accumulation } \\
\left(\mathrm{g} \mathrm{pot}^{-1}\right)\end{array}$} & \multirow[t]{2}{*}{${ }^{15} \mathrm{~N} \%$ excess } & \multirow{2}{*}{$\begin{array}{l}{ }^{15} \mathrm{~N} \text { uptake } \\
\left(\mathrm{mg} \mathrm{pot}^{-1}\right)\end{array}$} & \multicolumn{2}{|c|}{${ }^{15} \mathrm{~N}$ recovery $(\%)$} \\
\hline & & & & & & Leek & Total (leek + clover) \\
\hline \multirow[t]{6}{*}{ D3 } & \multicolumn{7}{|l|}{ Soil } \\
\hline & Aarslev & 0.7 & 0.022 & 1.4 & 0.3 & 2.1 & 27.6 \\
\hline & Foulum & 0.8 & 0.026 & 1.4 & 0.3 & 2.3 & 28.0 \\
\hline & \multicolumn{7}{|c|}{ Incorporation } \\
\hline & $\mathrm{F}$ & 0.6 & 0.021 & $1.7 \mathrm{a}$ & 0.3 & 2.4 & $2.4 \mathrm{~b}$ \\
\hline & $\mathrm{S} 1 / \mathrm{S} 2$ & 0.9 & 0.027 & $1.1 \mathrm{~b}$ & 0.3 & 2.0 & $45.9 \mathrm{a}$ \\
\hline \multirow[t]{7}{*}{ D4 } & \multicolumn{7}{|l|}{ Soil } \\
\hline & Aarslev & 2.7 & 0.091 & $4.4 \mathrm{a}$ & $3.7 \mathrm{a}$ & $26.3 \mathrm{a}$ & 30.2 \\
\hline & Foulum & 2.4 & 0.079 & $3.2 \mathrm{~b}$ & $2.5 \mathrm{~b}$ & $17.4 \mathrm{~b}$ & 25.0 \\
\hline & \multicolumn{7}{|c|}{ Incorporation } \\
\hline & $\mathrm{F}$ & 2.6 & $0.096 \mathrm{a}$ & $2.8 \mathrm{~b}$ & 2.8 & 19.5 & $19.5 \mathrm{~b}$ \\
\hline & $\mathrm{S} 1$ & 2.6 & $0.091 \mathrm{ab}$ & $3.6 \mathrm{ab}$ & 3.3 & 23.0 & $23.0 \mathrm{~b}$ \\
\hline & $\mathrm{S} 2$ & 2.3 & $0.068 \mathrm{~b}$ & $4.9 \mathrm{a}$ & 3.3 & 23.1 & $40.5 \mathrm{a}$ \\
\hline \multirow[t]{7}{*}{ D5 } & \multicolumn{7}{|l|}{ Soil } \\
\hline & Aarslev & 9.5 & 0.24 & - & - & - & - \\
\hline & Foulum & 9.5 & 0.27 & - & - & - & - \\
\hline & \multicolumn{7}{|c|}{ Incorporation } \\
\hline & $\mathrm{F}$ & 10.0 & 0.24 & - & - & - & - \\
\hline & $\mathrm{S} 1$ & 10.0 & 0.30 & - & - & - & - \\
\hline & $\mathrm{S} 2$ & 8.5 & 0.24 & - & - & - & - \\
\hline
\end{tabular}

The abbreviations of F, S1, S2, D3, D4 and D5 are explained in Table 1. The different letters indicate significant differences between soils or incorporation strategies at $p<0.05$. The dash means the entry is not applicable

soil $\mathrm{N}_{\text {inorg }}$ before leaching, which was higher than the $3.5 \%$ of total soil $\mathrm{N}_{\text {inorg }}$ in stepwise incorporations. At $\mathrm{D} 4$, the leachate volume was higher in treatment $\mathrm{F}$ than $\mathrm{S} 1$ and $\mathrm{S} 2$. The $\mathrm{N}$ concentration and $\mathrm{N}$ content were similar in treatments $\mathrm{F}$ and $\mathrm{S} 1$, but much higher than in treatment S2. Leachate volume was higher in S1 than in $\mathrm{S} 2$ and was higher in Aarslev soil than in Foulum soil. The proportion of $\mathrm{N}$ loss to the total soil $\mathrm{N}_{\text {inorg }}$ was higher in treatments $\mathrm{F}$ and $\mathrm{S} 1$ than in treatment $\mathrm{S} 2$.

\section{Discussion}

Influence of stepwise incorporations on leek growth and $\mathrm{N}$ accumulation

Stepwise incorporation resulted in higher leek $\mathrm{N}$ accumulation in both soils and higher biomass of leeks at the end of the experiment (D6) in Aarslev soil. Furthermore, stepwise incorporations led to a higher leek growth rate from D5 to D6 (late season), when leek growth was most rapid, relative to previous sampling intervals (data not shown). This finding suggests that it is possible to intercrop white clover and incorporate clover as split-dose fertiliser during the growing season to obtain good yields and high $\mathrm{N}$ uptake of leek. In a field experiment, incorporation of the second part of red clover 4 weeks after planting resulted in the lowest biomass and $\mathrm{N}$ accumulation of leeks, compared to incorporation 2 weeks after planting and full incorporation (Båth 2001). The different results were due to the competition on $\mathrm{N}$, which was controlled by root pruning in the present experiment but was strong in the field experiment.

The similar or lower leek $\mathrm{N}$ accumulation in stepwise incorporations at earlier growth stages (i.e. D3 and D4, Table 4) was probably due to lower soil $\mathrm{N}_{\text {inorg }}$ present in the early growing season. Only half of the white clover had been incorporated into the soil before these sampling times, and $\mathrm{N}$ was being taken up by the white clover growing in the other half of the pot (Table 3). 


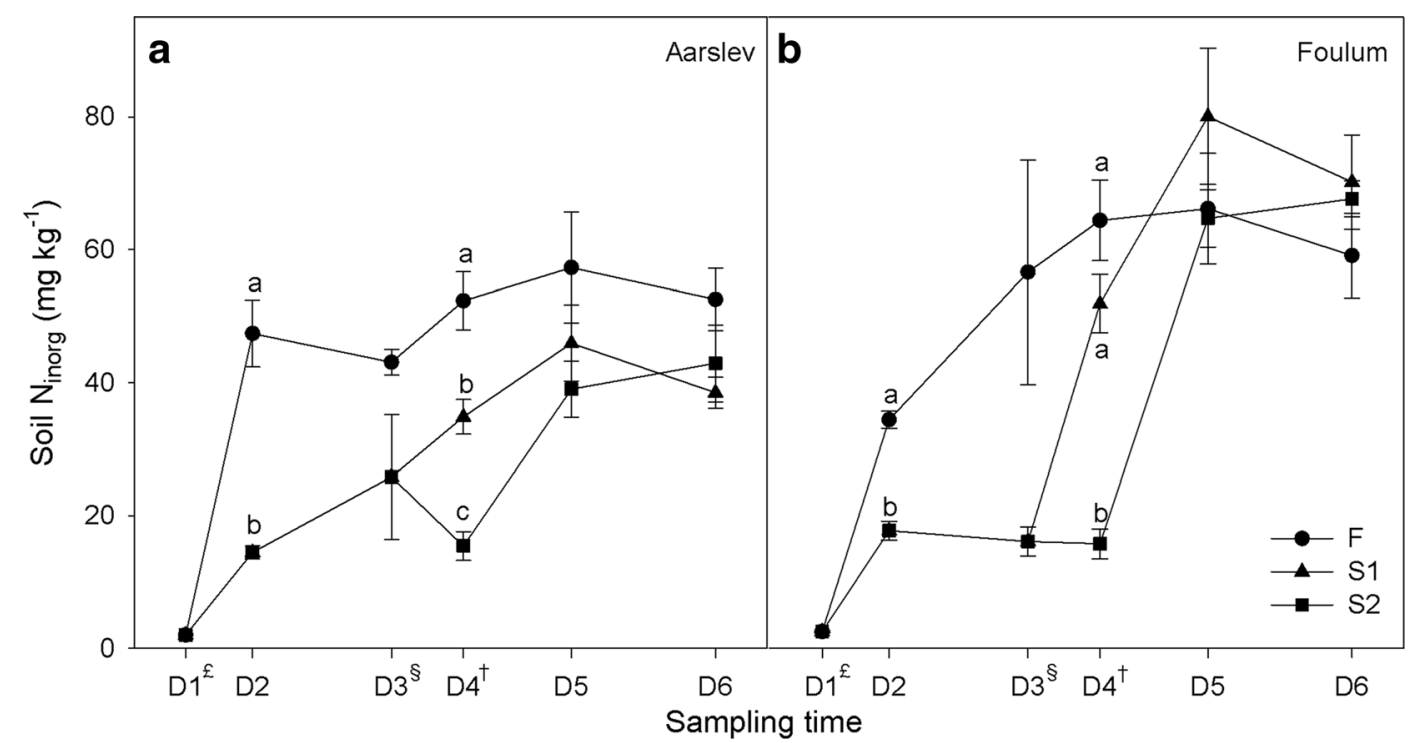

Fig. 3 The soil inorganic $\mathrm{N}\left(\mathrm{N}_{\text {inorg }}\right)$ at six sampling times for the incorporation strategies in the (a) Aarslev and (b) Foulum soils. $£$, $\S$ and $\dagger$ indicate the time of the full incorporation, second incorporation in S1 and second incorporation in S2, respectively. The

However, the $\mathrm{N}$ concentration of leeks (3.0-3.6\%) was still high in stepwise incorporations at D3 (26 days after transplanting) and D4 (41 days after transplanting) relative to a field study (Båth 2001), where the N concentration in transplanted leeks was $1.2 \%$ by 28 days after incorporation of red clover and leek transplantation and $2.2 \%$ by 42 days. Furthermore, a leek N concentration of $3.0 \%$ in the stepwise incorporations was indicated to be sufficient for leek growth, because leek biomasses following stepwise incorporations at D3, D4 and D5 were not significantly different from biomass following the full incorporation (Table 4).

The similar $\mathrm{N}$ accumulation in leeks among the three incorporation strategies across soils suggests the rapid mineralisation of white clover, which corresponded to an increase in soil $\mathrm{N}_{\text {inorg }}$ (Fig. 3 and Table 5). In Aarslev soil, the increased soil $\mathrm{N}$ concentration in stepwise incorporations did not result in differences in leek abbreviations F, S1, S2, D1, D2, D3, D4, D5 and D6 are explained in Table 1. The different letters indicate significant differences between incorporation methods at each time point and in each soil at $p<0.05$. Error bars indicate standard errors of the mean

biomass at D5 (data not shown), but in a higher biomass at D6 (Fig. 2a), which can be attributed to the high growth rate (Fig. 2b).

Due to the total $\mathrm{N}$ loss of $280 \mathrm{mg} \mathrm{pot}^{-1}$ in treatment $\mathrm{F}$ by the two leaching events during the growing period (D3 + D4, Table 6), the $\mathrm{N}$ accumulation in leeks was lowest in treatment F at D6 in both soils (Fig. 2c). Another reason was the lowest white clover $\mathrm{N}$ input in treatment $\mathrm{F}$ (Table 3). The low leek $\mathrm{N}$ accumulation in treatment $\mathrm{F}$ corresponded to the lowest leek $\mathrm{N}$ concentration at D6 (F: 1.6\%; S1: 2.2\%; S2: 3.0\%) and dry biomass in Aarslev soil. These results confirm hypothesis 1 that plant-available $\mathrm{N}$ following stepwise incorporations is better synchronised with the $\mathrm{N}$ demand and growth rates of leeks, thus resulting in higher leek biomass. The higher leek biomass in stepwise incorporations indicates that interspecific competition between leeks and white clover did not inhibit leek growth,

Table 5 The effects of soil on the change in soil inorganic $\mathrm{N}\left(\mathrm{N}_{\text {inorg }}\right)$ concentration between sampling times

\begin{tabular}{|c|c|c|c|c|c|c|}
\hline & \multicolumn{2}{|c|}{$\mathrm{F}\left(\mathrm{mg} \mathrm{kg}^{-1}\right)$} & \multicolumn{2}{|c|}{$\mathrm{S} 1\left(\mathrm{mg} \mathrm{kg}^{-1}\right)$} & \multicolumn{2}{|c|}{$\mathrm{S} 2\left(\mathrm{mg} \mathrm{kg}^{-1}\right)$} \\
\hline & Aarslev & Foulum & Aarslev & Foulum & Aarslev & Foulum \\
\hline From D3 to D4 (14 days) & 9.3 & 7.8 & $9.0 \mathrm{~b}$ & $35.8 \mathrm{a}$ & $-10.4 b$ & $-0.4 \mathrm{a}$ \\
\hline From D4 to D5 (21 days) & 5.0 & 1.8 & 11.1 & 28.2 & $23.6 \mathrm{~b}$ & $49.0 \mathrm{a}$ \\
\hline
\end{tabular}

The abbreviations F, S1, S2, D3, D4 and D5 are explained in Table 1. The second half of white clover in S1 and S2 was incorporated at D3 and D4, respectively. The different letters indicate significant differences between soils at $p<0.05$ within each sampling time and incorporation strategy 
Fig. 4 The ${ }^{15} \mathrm{~N}$ uptake by leek and white clover (WC) at D3 for $\mathrm{S} 1$ and D4 for S2 in two soils. The abbreviations S1, S2, D3 and D4 are explained in Table 1. The different letters indicate uptake at $p<0.05$ between leek and white clover in each soil. Error bars indicate standard errors of the mean significant differences in ${ }^{15} \mathrm{~N}$

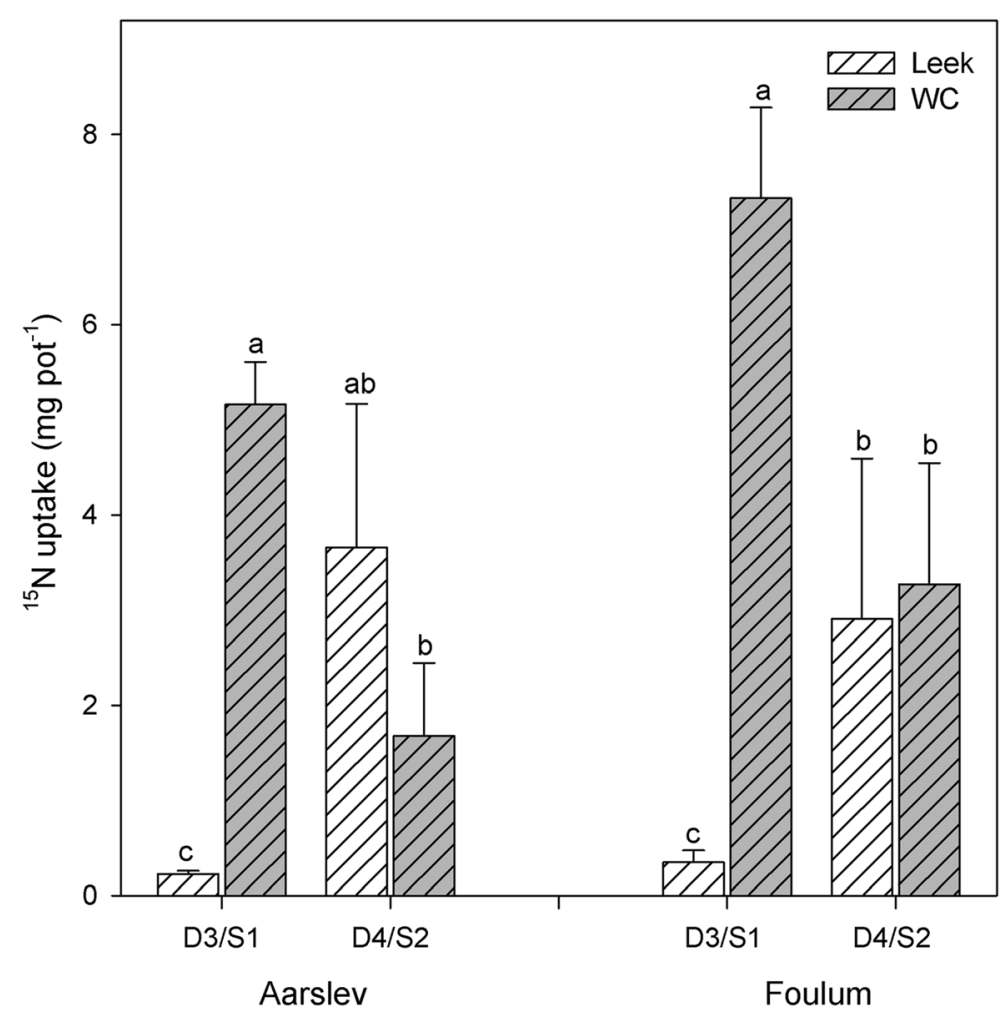

probably due to the control of competition by root pruning. In contrast, a previous study that did not prune roots found that the leek biomasses at 56 days after transplanting and at harvest were lowest when red clover was incorporated 28 days after transplanting, presumably due to interspecific competition during the initial period of growth (Båth 2001). Improvements in the growth and $\mathrm{N}$ uptake of leeks by split-dose inorganic fertilisation in a conventional cropping system were reported in another field study (Savic et al. 2004).

The positive influence of stepwise incorporations on leeks growth appeared earlier in Aarslev soil (D5) than Foulum soil (D6), probably due to a lower release of $\mathrm{N}$ from the soil organic $\mathrm{N}$ pool in Aarslev soil. Both soil organic and inorganic $\mathrm{N}$ concentrations were lower in Aarslev soil at the start of experiment (Table 2), and the net $\mathrm{N}$ mineralisation rate was indicated to be lower by the changes of soil $\mathrm{N}_{\text {inorg }}$ (Table 5).

Influence of stepwise incorporations and soils on soil $\mathrm{N}$ dynamics

Stepwise incorporation of intercropped white clover improved soil $\mathrm{N}$ dynamics by lowering $\mathrm{N}$ loss via leaching and increasing fixation of $\mathrm{N}$. Net mineralisation took place throughout the experiment, as confirmed by the increase of soil $\mathrm{N}_{\text {inorg }}$ (Fig. 3, Table 5), except in treatment S2 from D3 to D4. The increase of soil $\mathrm{N}_{\text {inorg }}$ in treatment S2 was probably hidden by leek and white clover $\mathrm{N}$ uptake. The increase in soil $\mathrm{N}_{\text {inorg }}$ from the first to second incorporation (S1: D1 to D3; S2: D1 to D4) was less than the increase in soil $\mathrm{N}_{\text {inorg }}$ in treatment $\mathrm{F}$, because of uptake by white clover and that less $\mathrm{N}$ was incorporated in the soil. Although soil $\mathrm{N}_{\text {inorg }}$ in treatment S2 decreased from D3 to D4, it increased to similar levels as those of treatments F and S1 after its second incorporation at D5 in both soils. These results resembled those of Båth (2001), where red clover was the green manure.

The reduced risk of nitrate leaching by stepwise incorporations was demonstrated by the low $\mathrm{N}_{\text {inorg }}$ leachate concentration and volume (Table 6), especially in the early growing season when the leek root system that the root system of leek was assumed to be poorly developed 26 days after transplanting (D3), based on our low ${ }^{15} \mathrm{~N}$ recovery in leek (Table 4 ). Because intercropped white clover increased both roots distributed in the soil and $\mathrm{N}$ uptake relative to treatment $\mathrm{F}$ was still small. This result confirmed our hypothesis 3 in 
Table 6 The effects of incorporation strategy and soil on leaching of inorganic $\mathrm{N}\left(\mathrm{N}_{\text {inorg }}\right)$ at the first and second leaching events

\begin{tabular}{|c|c|c|c|c|c|}
\hline Sampling time & Factor & $\begin{array}{l}{ }_{\text {Soil }} \mathrm{N}_{\text {inorg }} \text { before } \\
\text { leaching }\left(\mathrm{g} \mathrm{pot}^{-1}\right)\end{array}$ & $\begin{array}{l}\text { Volume } \\
\left(\mathrm{L} \mathrm{pot}^{-1}\right)\end{array}$ & $\begin{array}{l}\mathrm{N} \text { content } \\
\left(\mathrm{mg} \mathrm{pot}^{-1}\right)\end{array}$ & $\begin{array}{l}\mathrm{N} \text { loss } / \text { soil } \\
\mathrm{N}_{\text {inorg }}(\%)\end{array}$ \\
\hline \multirow[t]{6}{*}{ Prior to D3 } & Soil & & & & \\
\hline & Aarslev & 0.99 & 2.2 & 111 & 10.6 \\
\hline & Foulum & 0.96 & 2.0 & 98 & 8.7 \\
\hline & Incorpor & & & & \\
\hline & $\mathrm{F}$ & $1.41 \mathrm{a}$ & $2.9 \mathrm{a}$ & $193 \mathrm{a}$ & $15.9 \mathrm{a}$ \\
\hline & $\mathrm{S} 1 / \mathrm{S} 2$ & $0.53 \mathrm{~b}$ & $1.3 \mathrm{~b}$ & $16 \mathrm{~b}$ & $3.5 \mathrm{~b}$ \\
\hline \multirow[t]{7}{*}{ Prior to D4 } & Soil & & & & \\
\hline & Aarslev & $0.99 \mathrm{~b}$ & $2.2 \mathrm{a}$ & 57 & 6.3 \\
\hline & Foulum & $1.11 \mathrm{a}$ & $1.8 \mathrm{~b}$ & 60 & 5.0 \\
\hline & Incorpor & & & & \\
\hline & $\mathrm{F}$ & $1.51 \mathrm{a}$ & $2.5 \mathrm{a}$ & $86 \mathrm{a}$ & $6.0 \mathrm{a}$ \\
\hline & $\mathrm{S} 1$ & $1.11 \mathrm{~b}$ & $2.0 \mathrm{~b}$ & $84 \mathrm{a}$ & $8.2 \mathrm{a}$ \\
\hline & $\mathrm{S} 2$ & $0.54 \mathrm{c}$ & $1.4 \mathrm{c}$ & $6 \mathrm{~b}$ & $2.6 \mathrm{~b}$ \\
\hline
\end{tabular}

The abbreviations of F, S1, S2, D3 and D4 are explained in Table 1. The different letters indicate significant differences between incorporation strategies or soils at $p<0.05 .{ }^{\S}$ The soil $\mathrm{N}_{\text {inorg }}$ before leaching was calculated as the sum of $\mathrm{N}$ content in leachate and the soil $\mathrm{N}_{\text {inorg }}$ measured after the leaching event

(Table 3), the ability for $\mathrm{N}$ retention in the system increased, as supported also by the higher total ${ }^{15} \mathrm{~N}$ recovery (Table 4).

Few studies have investigated nitrate leaching with the stepwise incorporation of green manures as splitdose fertilisers. In a pot experiment using rice, splitdose fertilisation resulted in less $\mathrm{N}$ loss in the beginning of the season (Kamyab-Talesh et al. 2014). Stepwise incorporation of an intercropped legume as fertiliser is superior to split-dose fertilisation with animal manure because cover crops and living mulch take up water and nutrients and reduce drainage (Liedgens et al. 2004). Drainage was one of the main factors influencing the amount of soil $\mathrm{N}_{\text {inorg }}$ leached in our study. In practice, the leek plant is generally transplanted at the end of May in Denmark. In the early growth stage, when leek $\mathrm{N}$ uptake is low, the risk of $\mathrm{N}$ loss could be high during precipitation events. According to meteorological data from Aarslev, during the last 15 years (2000-2014), precipitation exceeded $30 \mathrm{~mm}$ on 9 days during the May to July period. There may be an increased risk of heavy rain in the future due to climate changes. Therefore, the management method of intercropping and stepwise incorporation of white clover as fertiliser over time has the potential to increase $\mathrm{N}$ retention in soils and reduce nitrate leaching in agricultural systems.
By incorporating white clover into soil in a stepwise manner, half of the clover was allowed to grow for a longer time (i.e. 39 and 54 days longer than treatment F). During these growth periods, white clover continuously fixed N, accounting for additional $68-77 \%$ of the amount of $\mathrm{N}$ incorporated in treatment F (D1) (Table 3). This result confirmed our hypothesis 2 , that stepwise incorporations provide more $\mathrm{N}$ to plants by $\mathrm{N}_{2}$ fixation. Although the NUE of leeks did not differ statistically among incorporation strategies at the end of experiment, the NUE was indicated to be higher in stepwise incorporations, when leek would reach to harvestable size, at least in Aarslev soil (Fig. 2c).

The net mineralisation rate was higher in Foulum than in Aarslev soil, as indicated by the larger increases (S1: D3 to D4; S2: D4 to D5) and smaller decrease (S2: D3 to D4) in soil $\mathrm{N}_{\text {inorg }}$ (Fig. 4), while leek and white clover $\mathrm{N}$ accumulation increased with time but was not affected by the soil types. The lower net mineralisation rate in Aarslev soil after white clover was incorporated could be attributed to its lower available P content and $\mathrm{P} / \mathrm{N}$ ratios relative to Foulum soil (Table 2). These differences were probably due to the different fertilisation strategies based on growing of legumes or application of animal manures, respectively. High $\mathrm{P}$ content stimulates $\mathrm{N}$ mineralisation by increasing microbial activity (Reed et al. 2007). Another reason for 
the lower net mineralisation rate in Aarslev soil could be that the added white clover contributed to the stable soil organic matter pool more in Aarslev soil than in the Foulum one. This was supported by the lower content of soil organic matter in Aarslev soil after the fallow period in 2014, with the possible depletion of the soil organic matter pool. The leachate volume was lower in Foulum soil at D4 (Table 6), which also could be related to the higher content of organic matter in this soil (Table 2), which is known to improve water retention capacity (Rawls et al. 2003). However, the higher leachate volume in Aarslev soil did not result in higher $\mathrm{N}$ loss (Table 6) because the $\mathrm{N}$ concentration of the leachate tended to be lower than that of the Foulum soil.

Influence of stepwise incorporations on available $\mathrm{N}$ for leek uptake

Stepwise incorporations, used as split-dose fertilisation, better matched leek's requirement for $\mathrm{N}$ than did treatment $\mathrm{F}$ (i.e. fertilisation at the beginning of the experiment), as confirmed by the $\mathrm{N}$ accumulation in leeks (Fig. 2c). The pattern of $\mathrm{N}$ accumulation in leek over time showed that a large amount of $\mathrm{N}$ was taken up in the later growth stage of leek. The large increase in soil $\mathrm{N}_{\text {inorg }}$ in the early growth stage in treatment F, compared to in stepwise incorporations, could not be utilised by leek due to the small plants size with small root systems in the early growth stage (Kristensen and ThorupKristensen 2007). Stepwise incorporations provided an increased $\mathrm{N}$ input for later growth stages (after the second incorporations) by increasing $\mathrm{N}_{2}$ fixation, allowing for soil $\mathrm{N}_{\text {inorg }}$ uptake of white clover during early growth stages of leek and by lowering the risk of $\mathrm{N}$ loss via leaching. The slight increase in soil $\mathrm{N}_{\text {inorg }}$ in $\mathrm{S} 2$ between D5 and D6 and decrease in S1 indicated that more soil $\mathrm{N}_{\text {inorg }}$ was released in $\mathrm{S} 2$, which could support further leek growth. These results indicate the great potential for using stepwise incorporation in organic farming systems, where initial soil $\mathrm{N}_{\text {inorg }}$ is often high (modelled in treatment F) after incorporating green manure prior to growing vegetables (Xie and Kristensen 2016). The high initial soil $\mathrm{N}_{\text {inorg }}$ is likely to exceed $\mathrm{N}$ uptake by vegetables in early growth stages, resulting in low NUE, if not proper field management is implemented. The field management should be focused on reducing $\mathrm{N}$ leaching, as occurs in European agroecosystems for example with cover crop-vegetable intercropping (Xie et al. 2016).
Fresh leek biomass per plant in all incorporation strategies at the end of experiment (99-185 $\mathrm{g} \mathrm{plant}^{-1}$ ) was lower than the range in biomass determined at harvest in a field experiment (245-292 g plant $\left.^{-1}\right)$, when the same cultivar was grown to harvestable size (Xie and Kristensen 2017). This confirms that the study focuses on the first part of the growing season, when the $\mathrm{N}$ demand is low and the root system of leek is small, and the risk of $\mathrm{N}$ loss by leaching is high.

\section{Competition for $\mathrm{N}$ between white clover and leek}

Interspecific competition for $\mathrm{N}$ existed in the stepwise incorporations but did not inhibit the ability of leek to obtain sufficient $\mathrm{N}$ and growth. The similar ${ }^{15} \mathrm{~N}$ uptakes at D3 and D4 between incorporation strategies (Table 4) indicated that the presence of white clover did not prevent leek from obtaining $\mathrm{N}$ (e.g. by altering root growth) (Hodge 2004). But the similar ${ }^{15} \mathrm{~N}$ uptakes suggested that total $\mathrm{N}$ uptakes by leek during ${ }^{15} \mathrm{~N}$ injection periods were higher in treatment $\mathrm{F}$ than in treatments S1 and S2. This suggestion was based on the higher level of dilution of ${ }^{15} \mathrm{~N}$ by soil ${ }^{14} \mathrm{~N}_{\text {inorg }}$ in the pool of $\mathrm{N}_{\text {inorg }}$ available for plant uptake (Powlson and Barraclough 1993) in treatment $F$, where soil $\mathrm{N}_{\text {inorg }}$ concentration was higher than in treatment S1 and S2. This finding was also true for accumulated N at D4. Soil $\mathrm{N}_{\text {inorg }}$ uptake of intercropped white clover in treatments $\mathrm{S} 1$ and $\mathrm{S} 2$ was represented by ${ }^{15} \mathrm{~N}$ uptake and $\mathrm{N}$ uptake from soil (Tables 4 and 5 and Fig. 4). These findings indicate that there was interspecific competition for soil $\mathrm{N}$, inconsistent with our hypothesis 4 . Competition for soil $\mathrm{N}$ was also found between intercropped pea (Pisum sativum L.) and barley (Hordeum vulgare L.) in a field study (Jensen 1996). However, the competition in our experiment did not limit leek growth when leek was grown with white clover. The higher ${ }^{15} \mathrm{~N}$ uptake by white clover than by leek at D3 (Fig. 4) was probably due to the differences in plant size (clover was larger) and plant ages between the two species.

In both soils at D4 (35 days after leek transplantation), the similarity in ${ }^{15} \mathrm{~N}$ uptake between leek and white clover could be attributed to the increased root development and increased $\mathrm{N}$ competitiveness of leek compared to (previously root-pruned) white clover. The decreased competiveness of white clover was confirmed by the lower ${ }^{15} \mathrm{~N}$ uptake by clover at time D4 compared to D3, when the soil $\mathrm{N}_{\text {inorg }}$ results were similar. A reduced ${ }^{15} \mathrm{~N}$ uptake by intercropped legumes induced 
by root pruning was also reported by Båth et al. (2008), who found hardly any ${ }^{15} \mathrm{~N}$ uptake by intercropped legumes after two root prunings, resulting in a similar total ${ }^{15} \mathrm{~N}$ uptake (by both cash crops and intercropped legumes) in intercropping and sole-cropping systems. In our study, competition for $\mathrm{N}$ did not inhibit leek growth, as confirmed by the similar dry biomasses of leeks in the stepwise- and full-incorporation treatments. In a field experiment with dyer's woad (Isatis tinctoria L.) as the intercrop species, no inhibition of leek growth but rather a facilitation was found (Xie and Kristensen 2017). In contrast, Xie et al. (2016) found that white clover outcompeted leeks when clover was sown 18 days after leek transplanting in Slovenia. Båth (2001) found that delaying the incorporation of red clover until 28 days after leek transplanting reduced yield in the first 56 days, compared to the incorporation after a delay of 14 days. Two circumstances probably led to the lack of competitive effect of white clover on leek growth in our study: the root pruning at D2 and D3 reduced interspecific competition, and the soil $\mathrm{N}_{\text {inorg }}$ was high compared to leek $\mathrm{N}$ demand.

\section{Conclusions}

Stepwise incorporations of intercropped white clover matched the temporal $\mathrm{N}$ availability with $\mathrm{N}$ demand by leeks and the leek growth rate. This effect was due to rapid $\mathrm{N}$ mineralisation of white clover after incorporation and increased $\mathrm{N}$ input for the later growth stages. Stepwise incorporations of white clover as fertiliser, in concert with the intercropping system, allowed clover to grow for a longer period and fix more $\mathrm{N}_{2}$, compared to the full incorporation (i.e. all fertiliser provided at the beginning of the growing period). The use of white clover in stepwise incorporations resulted in reduced $\mathrm{N}$ loss during artificial rain events by increasing $\mathrm{N}$ and water uptake in the system. The effects were more pronounced in the late than in the early stepwise incorporation. The influence of stepwise incorporations was larger in Aarslev soil compared to Foulum soil, which was related to lower content of soil organic matter, total $\mathrm{N}$ and available $\mathrm{P}$ in Aarslev soil due to different fertilisation strategies. Interspecific competition for $\mathrm{N}$ in the stepwise incorporations did not inhibit leek growth, probably due to root pruning of white clover and adequate soil available $\mathrm{N}$ for plant growth.
The stepwise incorporation of legume as fertiliser during crop production may be an efficient method for improving $\mathrm{N}$ management in organic leek production. It can supplement the internal $\mathrm{N}$ pool via $\mathrm{N}_{2}$ fixation by the legumes and improves $\mathrm{N}$ retention by crop plants, leading to higher or comparable yields in regions where high precipitation occurs in the early growing season.

Acknowledgements This study was a part of the SoilVeg project funded by the CORE organic PLUS (ERA-NET) and GUDP (Ministry of Environment and Food of Denmark) programs. We appreciate the skilled technical help from Connie Krogh Damgaard, Freja K. D. Rasmussen, Knud Erik Pedersen, Jens Elkjær, Jens Barfod and Lasse Vesterholt, and the statistical assistance from Kristian Morten Kristensen, Department of Agroecology, Aarhus University.

Open Access This article is distributed under the terms of the Creative Commons Attribution 4.0 International License (http:// creativecommons.org/licenses/by/4.0/), which permits unrestricted use, distribution, and reproduction in any medium, provided you give appropriate credit to the original author(s) and the source, provide a link to the Creative Commons license, and indicate if changes were made.

\section{References}

Andersen SN, Dresboll DB, Thorup-Kristensen K (2014) Root interactions between intercropped legumes and non-legumes-a competition study of red clover and red beet at different nitrogen levels. Plant Soil 378:59-72. https://doi.org/10.1007/s11104-013-2014-4

Båth B (2001) Nitrogen mineralization and uptake in leek after incorporation of red clover strips at different times during the growing period. Biol Agric Hortic 18:243-258

Båth B, Kristensen HL, Thorup-Kristensen K (2008) Root pruning reduces root competition and increases crop growth in a living mulch cropping system. J Plant Interact 3:211-221. https://doi.org/10.1080/17429140801975161

Bosatta E, Agren GI (1997) Theoretical analyses of soil texture effects on organic matter dynamics. Soil Biol Biochem 29:1633-1638. https://doi.org/10.1016/S0038-0717(97)00086-2

Campiglia E, Mancinelli R, Radicetti E, Marinari S (2011) Legume cover crops and mulches: effects on nitrate leaching and nitrogen input in a pepper crop (Capsicum annuum L.) Nutr Cycl Agroecosyst 89:399-412. https://doi.org/10.1007/s10705-010-9404-2

Cassman KG, Munns DN (1980) Nitrogen mineralization as affected by soil-moisture, temperature, and depth. Soil Sci Soc Am J 44:1233-1237

Čereković N, Pagter M, Kristensen HL, Pedersen HL, Brennan R, Petersen KK (2013) Effects of drought stress during flowering of two pot-grown blackcurrant (Ribes nigrum L.) cultivars. Sci Hortic 162:365-373. https://doi.org/10.1016/j. scienta.2013.08.026 
Chaves B, De Neve S, Hofman G, Boeckx P, Van Cleemput O (2004) Nitrogen mineralization of vegetable root residues and green manures as related to their (bio)chemical composition. Eur J Agron 21:161-170. https://doi.org/10.1016/j.eja.2003.07.001

Cookson WR, Abaye DA, Marschner P, Murphy DV, Stockdale EA, Goulding KWT (2005) The contribution of soil organic matter fractions to carbon and nitrogen mineralization and microbial community size and structure. Soil Biol Biochem 37:1726-1737. https://doi.org/10.1016/j.soilbio.2005.02.007

Hodge A (2004) The plastic plant: root responses to heterogeneous supplies of nutrients. New Phytol 162:9-24. https://doi. org/10.1111/j.1469-8137.2004.01015.x

Hussain SA, Ali S, Ahmed K, Hyder S, Akber M, Abbas Q, Najam-ul-Hassan S, Ali S, Ali K (2014) Gastrointestinal parasites and bacteria's in vegetables grown in soil treated with organic manure. J biodivers. Environ Sci 5:387-393

Jensen E (1996) Grain yield, symbiotic N2 fixation and interspecific competition for inorganic $\mathrm{N}$ in pea-barley intercrops. Plant Soil 182:25-38. https://doi.org/10.1007/bf00010992

Jones JB, Case VW (1990) Sampling, handling, and analyzing plant tissue samples. In: RL Westermann (ed) Soil testing and plant analysis. $3^{\text {rd }}$ edition. Soil Science Society of America book series no. 3, Wisconsin

Kamyab-Talesh F, Razavipour T, Rezaei M, Khaledian M (2014) The effect of urea fertilizer quantity and splitting on nitrate losses during rice growth season. Adv Environ Biol 8:357-363

Kristensen HL, Thorup-Kristensen K (2004) Uptake of N-15 labeled nitrate by root systems of sweet corn, carrot and white cabbage from 0.2-2.5 meters depth. Plant Soil 265:93-100. https://doi.org/10.1007/s11104-005-0696-y

Kristensen HL, Thorup-Kristensen K (2007) Effects of vertical distribution of soil inorganic nitrogen on root growth and subsequent nitrogen uptake by field vegetable crops. Soil Use Manag 23:338-347. https://doi.org/10.1111/j.14732743.2007.00105.x.

Liedgens M, Frossard E, Richner W (2004) Interactions of maize and Italian ryegrass in a living mulch system: (2) nitrogen and water dynamics. Plant Soil 259:243-258. https://doi. org/10.1023/b:plso.0000020965.94974.21

Malhi S, Johnston A, Gill K, Pennock D (2004) Landscape position effects on the recovery of $15 \mathrm{~N}$-labelled urea applied to wheat on two soils in Saskatchewan, Canada. Nutr Cycl Agroecosyst 68:85-93

Mueller T, Thorup-Kristensen K (2001) N-fixation of selected green manure plants in an organic crop rotation. Biol Agric Hortic 18: 345-363. https://doi.org/10.1080/01448765.2001.9754897

Odhiambo JJO, Bomke AA (2001) Grass and legume cover crop effects on dry matter and nitrogen accumulation. Agron J 93:299-307

Olesen JE, Askegaard M, Rasmussen IA (2000) Design of an organic farming crop-rotation experiment. Acta Agric Scand Sect B Soil Plant Sci 50:13-21. https://doi. org/10.1080/090647100750014367

Powlson DS, Barraclough D (1993) Mineralization and assimilation in soil-plant systems A2 - Knowles, Roger. In:
Blackburn TH (ed) Nitrogen Isotope Techniques. Academic Press, San Diego

Rawls WJ, Pachepsky YA, Ritchie JC, Sobecki TM, Bloodworth H (2003) Effect of soil organic carbon on soil water retention. Geoderma 116:61-76. https://doi. org/10.1016/S0016-7061(03)00094-6

Reed SC, Seastedt TR, Mann CM, Suding KN, Townsend AR, Cherwin KL (2007) Phosphorus fertilization stimulates nitrogen fixation and increases inorganic nitrogen concentrations in a restored prairie. Appl Soil Ecol 36:238-242. https://doi.org/10.1016/j.apsoil.2007.02.002

Savic D, Stikic R, Jovanovic Z (2004) Leek growth and productivity in response to light interception and nitrogen nutrition. Proc. Int'l. WS on Models Plant Growth \& Contr. Prod. Qual. in Hort Prod Fink M, Feller C (eds), International Society for Horticultural Science, Leuven, Belgium Acta Hort 654: 243-250

Sorensen JN (1992) Effect of catch crops on the content of soil mineral nitrogen before and after winter leaching. J Plant Nutr Soil Sci 155:61-66. https://doi.org/10.1002/jpln.19921550112

Thompson RB, Tremblay N, Fink M, Gallardo M, Padilla FM (2017) Tools and strategies for sustainable nitrogen fertilisation of vegetable crops. In: Tei F, Nicola S, Benincasa $\mathrm{P}$ (eds) Advances in research on fertilization management of vegetable crops. Springer International Publishing, Cham

VDLUFA Metodenbuch (1991) Bestimmung von leicht löslichen (pflanzenverfügbaren) Haupt- und Spurennährstoffen, Band I, Die Untersuchung von Böden, Darmstadt, Germany, Teil A6

Vos J, van der Putten PEL (1997) Field observations on nitrogen catch crops .1. Potential and actual growth and nitrogen accumulation in relation to sewing date and crop species. Plant Soil 195:299 309. https://doi.org/10.1023/A:1004281218996

Xie Y, Kristensen HL (2016) Overwintering grass-clover as intercrop and moderately reduced nitrogen fertilization maintain yield and reduce the risk of nitrate leaching in an organic cauliflower (Brassica oleracea L. Var. botrytis) agroecosystem. Sci Hortic 206:71-79. https://doi.org/10.1016/j.scienta.2016.04.034

Xie Y, Kristensen HL (2017) Intercropping leek (Allium porrum L.) with dyer's woad (Isatis tinctoria L.) increases rooted zone and agro-ecosystem retention of nitrogen. Eur J Agron 82(Part A):21-32. https://doi.org/10.1016/j.eja.2016.09.017

Xie Y, Tittarelli F, von Fragstein P, Bavec M, Canali S, Kristensen HL (2016) Can living mulches in intercropping systems reduce the potential nitrate leaching? Studies of organic cauliflower (Brassica oleracea L. Var. botrytis) and leek (Allium porrum L.) production across European conditions. Renew Agr Food Syst 32:224-239. https://doi. org/10.1017/S1742170516000211

Zotarelli L, Dukes MD, Scholberg JM, Hanselman T, Le Femminella K, Muñoz-Carpena R (2008) Nitrogen and water use efficiency of zucchini squash for a plastic mulch bed system on a sandy soil. Sci Hortic 116:8-16. https://doi. org/10.1016/j.scienta.2007.10.029 